\title{
HOW ATTITUDES, VISION AND ABILITY TO CAPTURE OPPORTUNITIES AFFECT STARTUPS' BUSINESS CREATIVITY
}

\author{
Pedro PALOS-SANCHEZ (D ${ }^{1}$, José Ramón SAURA (D) ${ }^{*}$, \\ Antonio GRILO (D) ${ }^{3}$, Rafael ROBINA RAMIREZ (D) 4 \\ ${ }^{1}$ International University of La Rioja, Faculty of Business and Communication, Department of Business \\ Organization, Marketing and Market Research, Av. de la Paz, 137, 26006 Logroño, Spain \\ ${ }^{2}$ Rey Juan Carlos University, Faculty of Social Sciences and Law, Department of Business Economics, \\ Paseo Artilleros s/n, Madrid 28032, Spain \\ ${ }^{3}$ NOVA University Lisbon, Faculdade de Ciências e Tecnologia, Campus FCT/UNL, UNIDEMI, \\ Monte da Caparica, 2829-519 Caparica, Portugal \\ ${ }^{4}$ University of Extremadura, Faculty of Business, Finance and Tourism, Department of Business \\ Management and Sociology, 10071 Caceres, Spain
}

Received 9 June 2019; accepted 23 April 2020

\begin{abstract}
This article examines the main factors that affect creativity in startups and how these factors influence entrepreneurial initiative strategies. Fifty individuals from the Extremadura region, Spain, participated in an online questionnaire in 2018 and 2019. SmartPLS was used to create a model of the interactions between variables. The results obtained have important theoretical and practical implications as they add new findings to the current literature on the role played by different factors in the creativity processes used by startups. The model has a strong predictive power $\left(\mathrm{R}^{2}=42.7 \%\right)$. This work describes internal factors such as the improvement in intellectual and attitudinal skills for identifying business opportunities as a preliminary step to taking creative business decisions, as well as shaping the future by coordinating potential efforts and actions.
\end{abstract}

Keywords: creativity, entrepreneurship, partial least squares structural equation modeling, startup business.

\section{Introduction}

The appearance of new technologies has created a business ecosystem which includes innovative projects that increase the amount of competition and added value, which are the main ways to obtain profitability in business initiatives (King \& Levine, 1993; Venkataraman, 2019; Aldrich \& Martinez, 2015).

\footnotetext{
*Corresponding author. E-mail: joseramon.saura@urjc.es
} 
An ecosystem of small technological companies which have their business strategies based on innovation has emerged in an environment of technological development (Yolanda \& Syuraini, 2019) and are known as startups (Ben Chikha \& Jarboui, 2017; Mas-Tur, Roig-Tierno, \& Ribeiro Soriano, 2016). Creativity and innovation are the reasons for the success of their projects (Ven, Hudson, \& Schroeder, 1984).

In an ecosystem of startups and entrepreneurial projects which use the techniques of digital marketing and the main strategies of data analysis and associated technologies (Saura \& Bennett, 2019). It is essential that the technological startups and entrepreneurial projects can detect opportunities and have a vision of the business sectors, which they are marketing to so that they can create successful projects (Almeida, Dokko, \& Rosenkopf, 2003; Yunis, Tarhini, \& Kassar, 2018).

Startups and entrepreneurial projects with technological innovation are usually supported by grants that come from institutions such as the university, government institutions for innovation (Sulistyo \& Siyamtinah, 2016), or start-up accelerators and incubators where business angels select and invest in creative innovation projects (Bennett, Pérez-Bustamante Yábar, \& Saura, 2017).

The themes and scopes of the business projects that startups detect and decide to develop are essential for the exponential development of the technology and projects (Lee, Hallak, \& Sardeshmukh, 2016). Another important point for the success of the business model is the ability of the startup team to implement creative strategies. These teams must be multidisciplinary, creative and expert in strategy and innovation (Zapatero et al., 2018; Saura, PalosSanchez, \& Grilo, 2019b).

The leadership capacity and the vision of the startups, as well as the initiative to generate new business models, is what is known as "pivoting" in the world of startups. Therefore, being able to pivot is essential for these business models to be solid in the long term (Kazanjian, Drazin, \& Glynn, 2002).

Likewise, creativity is the ability to develop ideas that can be used to satisfy the requested needs and demands. Creativity in startups is important for making an impact on the audience and transmitting the innovation to the audience in an effective way (Welter et al., 2017; Endrik et al., 2019).

The vision of a startup is the definition of the projected route to success for a startup or what it wants to become in the long term and is an important factor in the variable ecosystem of startups (Ven et al., 1984; Cooper \& Folta, 2017).

Initiative is also important in the world of startups as it determines the actions a company takes in a changing environment in which decisions must be taken on a daily basis to obtain a powerful project that can pivot and propose new strategies (Saura, Palos-Sanchez, \& Correia, 2019a). The creativity of startups can be seen to be important for successful projects (Zahra \& George, 2002; Hitt \& Ireland, 2017).

The aim of this research is to identify the main factors that affect creativity in innovative startups and entrepreneurial projects and how these can influence the strategies for the entrepreneurial initiative. This study used a methodological approach of structural 
equation analysis with partial least squares structural equation modeling (PLS-SEM) software.

The results of this research increase the bibliography for this research gap about the creativity of innovative startups and entrepreneurial projects and the generation of opportunities and initiative. The results of this research can also be used by innovative startups to improve their projects and creativity, along with their attitude and opportunity detection abilities in the technology and innovation ecosystem.

This investigation is structured in the following way. First, there is a review of the literature of the main research in this field. Second, the methodology and development of the hypotheses is explained. Next, the analysis of the results and discussion are presented and finally, the conclusions.

\section{Literature review}

Research has been done into different aspects of the ecosystem of startups and entrepreneurial projects using innovation in the last decade (Hooi et al., 2016; Kiani Mavi \& Amin Afshar, 2017). Saura et al. (2019b) continued the research presented by Farinha et al. (2017) and Aisyah, Musa, and Ramli (2017) and presented a methodological approach to the study of the main indicators that make a startup successful. References to creativity, innovation, equipment and technology are all included in that study.

Robina-Ramírez, Fernández-Portillo, and Díaz-Casero (2019) analyzed indicators for environmental startups, which means, the innovation and creativity processes in a new model of environmental valuation for newly created companies. Mazzarol et al. (1998) defined the role and importance of creativity in companies as a factor that motivates the success of business projects. Helbert (2016) studied the influence of creativity in startups, but in periods of crisis, in order to understand whether lack of creativity can negatively influence the crisis.

Bennett et al. (2017) investigated the influence that universities have on the creativity of startup and entrepreneurial projects that are carried out in this ecosystem, as well as measuring the social values and the creativity of the innovation in these types of projects.

Almeida et al. (2003) studied the mechanisms that startups have to detect opportunities and what their capacity is to make decisions in terms of motivation, enthusiasm and attitude. Aldrich and Martinez (2015) looked into the reason why entrepreneurs are not more creative and studied the relationship between creativity and innovation in order to define the factors that affect this relationship.

Chu et al. (2004) investigated the influence of attitude and discipline on the creativite strategies at startups.

Ensley, Hmieleski, and Pearce (2006) studied the importance of leadership in startups and entrepreneurial projects in order to manage teams correctly. The study also looked into how leadership affects the innovation and creativity of the projects being worked on.

Table 1 shows other studies that have studied creativity in startups with the approach proposed in this research. 
Table 1. Similar studies of creativity and startups (source: created by authors)

\begin{tabular}{|l|l|}
\hline \multicolumn{1}{|c|}{ Authors } & \multicolumn{1}{c|}{ Description } \\
\hline Rutten (2014) & $\begin{array}{l}\text { Show the influence of creativity in the development of startup } \\
\text { projects by performing a partial least squares structural } \\
\text { equation modeling analysis. }\end{array}$ \\
\hline $\begin{array}{l}\text { Duchesne, Kourti, and MacGregor } \\
\text { (2002) }\end{array}$ & $\begin{array}{l}\text { Performs a statistical process control type analysis to measure } \\
\text { the time taken in the process changing strategies of startups } \\
\text { (pivoting) taking into account variables such as innovation } \\
\text { and creativity. }\end{array}$ \\
\hline Howley and Malamis (2014) & $\begin{array}{l}\text { Develops a partial least squares path modeling to measure } \\
\text { the influence of hidden metrics in the creation of startup } \\
\text { strategies. }\end{array}$ \\
\hline Endrik et al. (2019) & $\begin{array}{l}\text { Study the factors that influence digital startup sustainability } \\
\text { with a partial least squares structural equation modeling for } \\
\text { the analysis of startups in Indonesia. }\end{array}$ \\
\hline Saura et al. (2019b) & $\begin{array}{l}\text { Develops an approach using data mining and Latent Dirichlet } \\
\text { allocation model to analyse the issues that influence the } \\
\text { success of startups taking into account motivation, technology } \\
\text { and creativity. }\end{array}$ \\
\hline
\end{tabular}

\section{Hypothesis development}

The following constructs were proposed to measure the influence of creativity variables in startups (see Figure 1). Attitude is the predisposition that startup teams have when facing new challenges. Vision consists of the perception that startups have when visualizing their long-term objectives in order to achieve them. Ability to identify opportunities refers to the ability of startups to identify and discover business opportunities that allow them to grow. Capture of opportunities refers to the implementation of the identified opportunities (DiPietro \& Anoruo, 2006; Freeman \& Engel, 2007; Audretsch \& Belitski, 2013; Rutten, 2014; Endrik et al., 2019) Initiative measures the degree to which startups start new projects and execute new strategies demanded by the market (Rutten, 2014).

Research by Audretsch and Belitski (2013) showed that attitude has an important influence on the creativity of entrepreneurial projects which use the theory of knowledge in their research. Ven, Hudson, and Schroeder (1984) stated that attitude, along with creativity in the development of new startups is of great importance for their success. These investigations and the link between attitude and creativity led to the following hypotheses:

H1. The attitude of the startups' teams influences the creativity of the startups' strategies.

Saura et al. (2019b) highlighted the importance of teams and their attitude and motivation for success when facing new challenges in a digital ecosystem. Reynolds (2001) also linked the attitude of startups with the vision and consolidation of their business projects after measuring the background of business startups. The following hypothesis was proposed using these investigations (Duchesne et al., 2002).

H2. The teams' attitude influences the vision for startup projects.

Freeman and Engel (2007) linked the ability to identify opportunities for creativity with the development of innovation models in startups. Marlet and van Woerkens (2004) carried out a 
study to find the skills that accompany creativity in the identification of opportunities (Howley \& Malamis, 2014). The following hypothesis was proposed from these investigations:

H3. The ability to identify opportunities for startup teams influences the creativity of their strategies.

Kuo and Gerber (2012) set out the principles of creativity in crowdfunding platforms startups, and identified the skills that startups need to identify opportunities in environments that satisfy the vision of the startup (Nambisan, 2017; Meyer et al., 2002). Endrik et al. (2019) looked at the sustainability of startups and studied the factors that help identify new business models and opportunities for this type of business. The following hypothesis was therefore proposed:

H4. The ability of startup teams to identify opportunities influences the vision of startup projects.

DiPietro and Anoruo (2006) studied how innovation and creativity influenced export performance. In their study, Creativity was found to have positive effects on the ability to detect opportunities. In addition, Montiel Campos et al. (2015) used a creative thinking style model to detect opportunities for startups and linked the influence of creativity to this decision making process (Endrik et al., 2019). The following hypothesis was therefore proposed:

H5. The creativity of startup strategies influences the ability of startup teams to detect opportunities.

Montiel Campos et al. (2015) used a design thinking model and discovered that the ability of entrepreneurs to identify opportunities is linked to the effectiveness of the initiative when creating new projects or opening new lines of products. Kuo and Gerber (2012) referred to entrepreneurship when talking about crowd funding startups that use creativity as a main tool in their business processes. The following hypothesis was proposed from this research:

H6. The ability to identify startup opportunities influences the initiative to pivot or develop new strategies.

Freeman and Engel (2017) found that the startup team's vision of innovative projects helps it to face new opportunities and execute them correctly because of its capacity for innovation and creativity. The successful identification and development of new opportunities is important for the vision of new startup projects (Endrik et al., 2019). The following research hypothesis was then proposed:

H7. The vision of startup projects influences the capture of new opportunities.

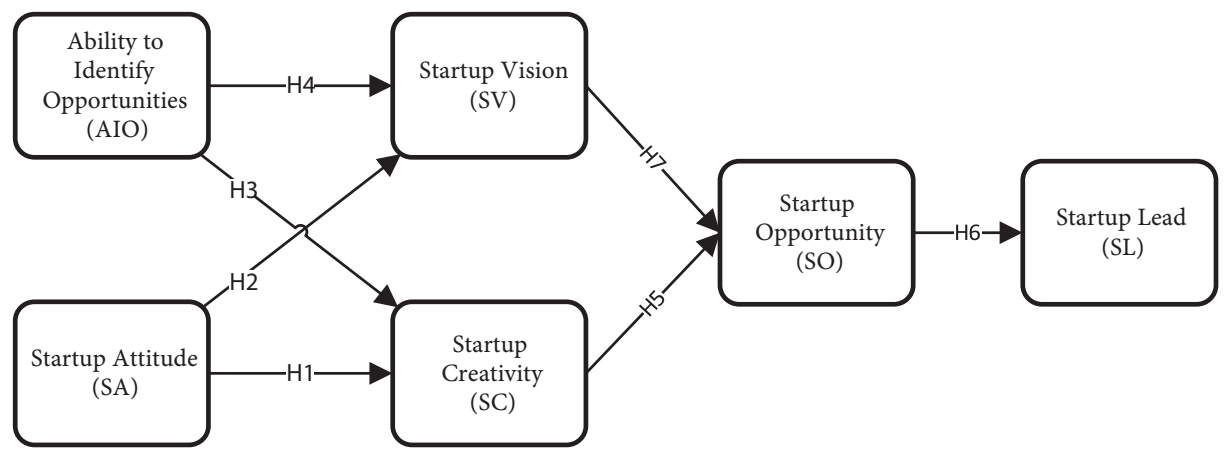

Figure 1. The proposed model (source: created by authors) 


\section{Methodology}

An empirical study was used to test the hypotheses. This consisted of an electronically administered questionnaire for residents of the Extremadura region in Spain. The electronic survey was available on the www.diagnosticoemprende.com website of the regional government. The questionnaire is a tool that surveys and shows the results of strengths and weaknesses on a polar graph.

\subsection{Data sample}

The questionnaires were offered to participants $(n=1547)$ who were selected with the help of the entrepreneur guidance and support services of the regional government. The participants had previously requested funds or technical support for a startup. A pretest with a sample of 46 individuals was used to validate the questionnaire and obtain comments on its structure, the order of the questions and the content in order to refine it. University students, technicians, professors and researchers of entrepreneurship at the university and Government de Extremadura were invited to take part in this pretest group. All incomplete questionnaires, those that contained systematic or inconsistent answers and any observations that did not meet the criteria suggested by Hair et al. (2017) were eliminated from the sample. These answers were not added to the final sample, but they did serve to modify the wording of some items. The questionnaire data was collected between January 2018 and February 2019.

Table 2 shows the profile of the members of the sample, where it can be seen that most of the respondents were women. The final sample was made up of 1547 people. The educational levels were: primary education $31.4 \%$ (485), secondary education $32.7 \%$ (506), university studies $34.7 \%$ (537) and special entrepreneurship training programs 1.2\% (19). Another variable that was measured was the place of residence of the entrepreneur: $25.7 \%$ (397) came from cities with less than 75,000 inhabitants, $18.0 \%$ (279) from towns with 20 000-75 000 inhabitants, $21.1 \%$ (327) from villages of 5000-20 000 inhabitants and 35.2\% (544) from places with less than 5000 inhabitants. More than $70 \%$ of the respondents are in the process of creating the company. That is to say, it is businesses that are starting up and are part of an innovative idea, generally associated with technological development. The rest have been in business for less than 3 years.

Table 2. Profile of respondents $(\mathrm{n}=1547)$ (source: created by authors)

\begin{tabular}{|c|c|c|c|c|c|}
\hline \multicolumn{2}{|c|}{ Sexo } & \multicolumn{3}{c|}{ Age } & Residence \\
\hline Woman & Man & $<25$ years & 25 years $\leq \mathrm{x} \leq 45$ years & $>45$ years & Region \\
\hline $47.30 \%$ & $52.70 \%$ & $16.20 \%$ & $48.78 \%$ & $36.02 \%$ & $\begin{array}{c}\text { Extremadura, } \\
\text { Spain }\end{array}$ \\
\hline
\end{tabular}

\subsection{Measuring instruments}

All the constructs were measured with a five-point Likert scale using indicators taken from the theoretical review, where $1=$ total disagreement and $5=$ total agreement. The ability to identify opportunities (AIO) construct was measured with three items, which were: AIO1 - 
I value opportunities in social, cultural and economic terms, AIO2 - I value the potential of an idea to create value and AIO3 - I identify the most appropriate way to maximize my entrepreneurial idea.

The startup attitude (SA) construct was measured with 4 items: SA1 - I am confident in myself, SA2 - I am aware of my needs and aspirations in the short, medium and long term, SA3 - I know my individual and group strengths and weaknesses and, last, SA4 - I believe in my ability to influence the course of events, despite uncertainty, setbacks and temporary failures.

The startup vision (SV) construct was measured with 3 items: SV1 - I am able to imagine the future, SV2 - I am able to turn ideas into action and SV3 - I am able to imagine future scenarios, which helps me coordinate efforts and actions.

The startup creativity (SC) construct was measured with 3 items: SC1 - I am able to work on several ideas and opportunities at the same time, SC2 - I try innovative approaches, and SC3 - I combine knowledge and resources to achieve results daily.

The startup opportunity (SO) construct was also measured with 3 items: SO1 - I identify and take advantage of opportunities to create value in my social, cultural and economic environment, SO2 - I identify the needs and challenges that must be met, and SO3 - I am capable of finding opportunities in my environment to create value.

The most endogenous construct of the model was startup leadership (SL). This was measured with 3 items: SL1 - I consider myself a person with entrepreneurial initiative, SL2 challenges do not worry me, and SL3 - I am an independent worker when carrying out planned tasks.

\subsection{Data analysis techniques}

The PLS technique was used to test the proposed model. This is an approach used to model structural equations with variance and SmartPLS 3.2.7 software (Ringle, Silva, \& Bido, 2014). There are various reasons for this choice, such as, the constructs in the model are composite and therefore suitable for the application of PLS (Roldán \& Sánchez-Franco, 2012). Also, this aim of this study is to identify the constructs that can help the reputation and image of the national brand (Hair, Ringle, \& Sarstedt, 2011). All the constructs were modeled in Mode A.

\section{Results}

\subsection{Measurement model}

The measurement model was used to evaluate all the constructs estimated as Mode A. The traditional measurements of internal consistency, reliability and validity were calculated for these constructs (Henseler, Ringle, \& Sarstedt, 2016). As a general rule, a satisfactory value for reliability is obtained when the values of both the indicators and the dimensions exceed 0.7. In our case, all the indicators of the Mode A constructs exceed this critical value (Table 3). In addition, the composite reliability was higher than 0.7 (Table 3), thus meeting the requirements. 
Table 3. Results of the measurement model (source: created by authors)

\begin{tabular}{|c|c|c|c|c|}
\hline $\begin{array}{l}\text { Construct/ } \\
\text { Indicator }\end{array}$ & & Reliability & $\begin{array}{l}\text { Composite } \\
\text { reliability }\end{array}$ & $\begin{array}{l}\text { Average } \\
\text { variance } \\
\text { extracted }\end{array}$ \\
\hline $\begin{array}{l}\text { Ability to identify } \\
\text { opportunities (AIO) }\end{array}$ & & & 0.896 & 0.742 \\
\hline AIO1 & I am confident in myself. & 0.801 & & \\
\hline $\mathrm{AIO} 2$ & $\begin{array}{l}\text { I am aware of my needs and } \\
\text { aspirations in the short, medium } \\
\text { and long term. }\end{array}$ & 0.809 & & \\
\hline $\mathrm{AIO} 3$ & $\begin{array}{l}\text { I know my individual and group } \\
\text { strengths and weaknesses. }\end{array}$ & 0.791 & & \\
\hline $\mathrm{AIO} 4$ & $\begin{array}{l}\text { I believe in my ability to } \\
\text { influence the course of events, } \\
\text { despite uncertainty, setbacks and } \\
\text { temporary failures. }\end{array}$ & 0.818 & & \\
\hline Startup creativity (SC) & & & 0.875 & 0.701 \\
\hline SC1 & $\begin{array}{l}\text { I am able to work on several ideas } \\
\text { and opportunities at the same time. }\end{array}$ & 0.863 & & \\
\hline SC2 & I try innovative approaches. & 0.838 & & \\
\hline SC3 & $\begin{array}{l}\text { I combine knowledge and } \\
\text { resources to achieve results daily. }\end{array}$ & 0.810 & & \\
\hline Startup lead (SL) & & & 0.857 & 0.669 \\
\hline SL1 & $\begin{array}{l}\text { I consider myself a person with } \\
\text { entrepreneurial initiative. }\end{array}$ & 0.866 & & \\
\hline SL2 & Challenges do not worry me. & 0.858 & & \\
\hline SL3 & $\begin{array}{l}\text { I am an independent worker when } \\
\text { carrying out planned tasks. }\end{array}$ & 0.722 & & \\
\hline $\begin{array}{l}\text { Startup opportunity } \\
\text { (SO) }\end{array}$ & & & 0.903 & 0.756 \\
\hline SO1 & $\begin{array}{l}\text { I identify and take advantage of } \\
\text { opportunities to create value in } \\
\text { my social, cultural and economic } \\
\text { environment. }\end{array}$ & 0.879 & & \\
\hline $\mathrm{SO} 2$ & $\begin{array}{l}\text { I identify the needs and challenges } \\
\text { that must be met. }\end{array}$ & 0.868 & & \\
\hline $\mathrm{SO} 3$ & $\begin{array}{l}\text { I am capable of finding } \\
\text { opportunities in my environment } \\
\text { to create value. }\end{array}$ & 0.863 & & \\
\hline Startup vision (SV) & & & 0.878 & 0.706 \\
\hline SV1 & I am able to imagine the future. & 0.789 & & \\
\hline SV2 & I am able to turn ideas into action. & 0.844 & & \\
\hline SV3 & $\begin{array}{l}\text { I am able to imagine future } \\
\text { scenarios, which helps me } \\
\text { coordinate efforts and actions. }\end{array}$ & 0.885 & & \\
\hline
\end{tabular}


To demonstrate the convergent validity of the Mode A constructs, the average variance extracted (AVE) was calculated. In our model all constructs and dimensions satisfy this criterion since their AVE value exceeds the minimum level of 0.5 (Table 3).

Two methods were used to find the discriminant validity, which indicates that each construct differs from the other constructs. Firstly, the value of correlation squared for the construct must not exceed the value of the AVE (Fornell \& Larcker, 1981). The HeterotraitMonotrait Ratio of Correlations (HTMT) is another value which was checked (Henseler, Ringle, \& Sarstedt, 2015). All the values in the matrix are below 0.85 (Kline, 2010), and the confidence intervals for HTMT do not reach the value of 1 (Henseler et al., 2015) so discriminant validity can be accepted (Table 4 ).

Table 4. Measurement model: discriminant validity (source: created by authors)

\begin{tabular}{|c|c|c|c|c|c|c|}
\hline \multicolumn{7}{|c|}{ Fornell-Larcker Criterion } \\
\hline & $\begin{array}{l}\text { Ability to } \\
\text { identify } \\
\text { opportunities } \\
\text { (AIO) }\end{array}$ & $\begin{array}{c}\text { Startup } \\
\text { attitude (SA) }\end{array}$ & $\begin{array}{l}\text { Startup } \\
\text { creativity } \\
\text { (SC) }\end{array}$ & $\begin{array}{l}\text { Startup lead } \\
\text { (SL) }\end{array}$ & $\begin{array}{l}\text { Startup } \\
\text { opportunity } \\
\text { (SO) }\end{array}$ & $\begin{array}{l}\text { Startup vision } \\
\text { (SV) }\end{array}$ \\
\hline AIO & 0.861 & & & & & \\
\hline SA & 0.654 & 0.805 & & & & \\
\hline SC & 0.753 & 0.638 & 0.837 & & & \\
\hline SL & 0.657 & 0.653 & 0.652 & 0.818 & & \\
\hline SO & 0.753 & 0.674 & 0.770 & 0.653 & 0.870 & \\
\hline SV & 0.736 & 0.641 & 0.723 & 0.639 & 0.685 & 0.840 \\
\hline \multicolumn{7}{|c|}{ Heterotrait-Monotrait Ratio of Correlations } \\
\hline & $\begin{array}{l}\text { Ability to } \\
\text { identify } \\
\text { opportunities } \\
\text { (AIO) }\end{array}$ & $\begin{array}{c}\text { Startup } \\
\text { attitude (SA) }\end{array}$ & $\begin{array}{l}\text { Startup } \\
\text { creativity } \\
\text { (SC) }\end{array}$ & $\begin{array}{l}\text { Startup lead } \\
\text { (SL) }\end{array}$ & $\begin{array}{l}\text { Startup } \\
\text { opportunity } \\
\text { (SO) }\end{array}$ & $\begin{array}{c}\text { Startup vision } \\
\text { (SV) }\end{array}$ \\
\hline \multicolumn{7}{|l|}{$\mathrm{AIO}$} \\
\hline SA & 0.790 & & & & & \\
\hline SC & 0.841 & 0.788 & & & & \\
\hline SL & 0.818 & 0.815 & 0.830 & & & \\
\hline $\mathrm{SO}$ & 0.847 & 0.81 & 0.844 & 0.802 & & \\
\hline SV & 0.845 & 0.786 & 0.840 & 0.808 & 0.831 & \\
\hline
\end{tabular}

In order to control the possible bias attributable to the measurement variable, the procedure recommended by Podsakoff et al. (2003) was applied. In addition, a complete collinearity test for variance inflation factor (VIF) was used in order to detect possible biases of Kock (2015). The guidelines followed were those described by Kock and Lynn (2012), who proposed this test to evaluate both vertical and lateral collinearity. Kock (2015) showed that when a VIF reaches a value higher than 3.3 (see Table 5), there is an indication of pathological collinearity. This warns that the model may be affected by common method biases. 
Table 5. Variance inflation factors (source: created by authors)

\begin{tabular}{|c|c|c|c|c|c|}
\hline $\begin{array}{c}\text { Ability to } \\
\text { identify } \\
\text { opportunities } \\
\text { (AIO) }\end{array}$ & $\begin{array}{c}\text { Startup } \\
\text { attitude (SA) }\end{array}$ & $\begin{array}{c}\text { Startup } \\
\text { creativity (SC) }\end{array}$ & $\begin{array}{l}\text { Startup lead } \\
\text { (SL) }\end{array}$ & $\begin{array}{c}\text { Startup } \\
\text { opportunity } \\
\text { (SO) }\end{array}$ & $\begin{array}{c}\text { Startup } \\
\text { vision (SV) }\end{array}$ \\
\hline AIO & & 1.748 & & & 1.748 \\
\hline SA & & 1.748 & & & 1.748 \\
\hline SC & & & & 2.093 & \\
\hline SL & & & & & \\
\hline SO & & & 1 & & \\
\hline SV & & & & 2.093 & \\
\hline
\end{tabular}

\subsection{Structural model}

Bootstrapping (5000 samples) was also performed to find both the t-values and the confidence intervals which allow the statistical significance of the relationships to be found (Roldán \& Sánchez-Franco, 2012).

As can be seen in Table 6, the empirical evidence revealed that there is a significant relationship between SA and SC (H1), with a confidence level higher than $99.9 \%(\beta=0.254$; $\mathrm{t}=9.658$ ), which means that this relationship is supported. Similarly, H2 is supported with the same confidence level, so SA influences SV $(\beta=0.279 ; \mathrm{t}=11.240)$.

The relationship of AIO with SC $(\mathrm{H} 3, \beta=0.587 ; \mathrm{t}=24.159)$ and with $\mathrm{SV}(\mathrm{H} 4, \beta=0.554$; $\mathrm{t}=22.679)$ is also supported with confidence levels above $99.9 \%$. These two hypotheses (H3 and $\mathrm{H} 4)$, together with $\mathrm{H} 5$ and $\mathrm{H} 6$ have the largest values in the model. $\mathrm{H} 5$ is the relationship of SC with SO $(\beta=0.575 ; t=22.918)$ and $\mathrm{H} 6$ is the influence of SO on SL $(\beta=0.653$; $\mathrm{t}=36.042)$. H6 is the relationship that has the highest statistical values and therefore the relationship with greatest influence in the model.

Finally, H7 was also found to be supported. So SV influences SO $(\beta=0.269 ; \mathrm{t}=9.933)$.

After examining the size of the effects (f2) in Table 6, Cohen and Howe (1988) show that SO has a great effect on SL (0.744), AIO on SC (0.499), AIO on SV (0.425) and SC on SO (0.425). The effect of SA on SV is only average (0.108). The effects of SA on SC and, of SV on SO are at a level that can only be considered as low (0.093).

Table 7 shows the explanatory capacity of our research model (R2). In addition, the coefficient of determination (R2) was examined to evaluate the explanatory power of endogenous constructs and showed the amount of variance of a construct that is explained by the predictive variables of said endogenous construct in the model (Chin, 2010; Chin \& Dibbern, 2010). Therefore, in the proposed model, SL explains $42.70 \%$ of the complete model. SO explains $62.80 \%$, which together with SC explains $60.50 \%$ (Table 7). Finally, SV explains $58.70 \%$.

The predictive importance of the constructs can be found by using the blindfolding technique. All values of Q2 found to be above zero when using blindfolding procedures show that the predictive relevance for endogenous constructs is supported (Table 7).

The SRMR adjustment index was also found to be 0.061 , which is lower than the recommended maximum value of 0.08 , confirming the good fit of the global model. 
Table 6. Results of the structural model (source: created by authors)

\begin{tabular}{|l|c|c|c|c|c|c|}
\hline & Path & p- values & t-statistic & $\begin{array}{c}\text { Confidence } \\
\text { interval }\end{array}$ & f2 & Supported \\
\hline $\begin{array}{l}\text { Ability to identify } \\
\text { opportunities } \\
\rightarrow \text { Startup creativity }\end{array}$ & 0.587 & $0.00^{* * *}$ & 24.159 & $\begin{array}{c}{[0.538 ;} \\
0.634]\end{array}$ & 0.499 & Yes \\
\hline $\begin{array}{l}\text { Ability to identify } \\
\text { opportunities } \\
\rightarrow \text { Startup vision }\end{array}$ & 0.554 & $0.00^{* * *}$ & 22.679 & $\begin{array}{c}{[0.506 ;} \\
0.602]\end{array}$ & 0.425 & Yes \\
\hline $\begin{array}{l}\text { Startup attitude } \\
\rightarrow \text { Startup creativity }\end{array}$ & 0.254 & $0.00^{* * *}$ & 9.658 & $\begin{array}{c}{[0.204 ;} \\
0.306]\end{array}$ & 0.093 & Yes \\
\hline $\begin{array}{l}\text { Startup attitude } \\
\rightarrow \text { Startup vision }\end{array}$ & 0.279 & $0.00^{* * *}$ & 11.240 & $\begin{array}{c}{[0.230 ;} \\
0.329]\end{array}$ & 0.108 & Yes \\
\hline $\begin{array}{l}\text { Startup creativity } \\
\rightarrow \text { Startup opportunity }\end{array}$ & 0.575 & $0.00^{* * *}$ & 22.918 & $\begin{array}{c}{[0.527 ;} \\
0.625]\end{array}$ & 0.425 & Yes \\
\hline $\begin{array}{l}\text { Startup opportunity } \\
\rightarrow \text { Startup lead }\end{array}$ & 0.653 & $0.00^{* * *}$ & 36.042 & $\begin{array}{c}{[0.617 ;} \\
0.688]\end{array}$ & 0.744 & Yes \\
\hline $\begin{array}{l}\text { Startup vision } \\
\rightarrow \text { Startup opportunity }\end{array}$ & 0.269 & $0.00^{* * *}$ & 9.933 & $\begin{array}{c}{[0.216 ;} \\
0.322]\end{array}$ & 0.093 & Yes \\
\hline
\end{tabular}

${ }^{* *} \mathrm{p}<0.001,{ }^{* *} \mathrm{p}<0.01,{ }^{*} \mathrm{p}<0.05$, ns: not significant

$\mathrm{t}(0.05 ; 4999)=1.64791345 ; \mathrm{t}(0.01 ; 4999)=2.333843952 ; \mathrm{t}(0.001 ; 4999)=3.106644601$

Sig. 0.05

Table 7. Effects of endogenous variables (source: created by authors)

\begin{tabular}{|l|c|c|}
\hline \multicolumn{1}{|c|}{ Constructs } & R2 & Q2 \\
\hline Startup creativity & 0.605 & 0.407 \\
Startup lead & 0.427 & 0.269 \\
Startup opportunity & 0.628 & 0.455 \\
\hline Startup vision & 0.587 & 0.396 \\
\hline
\end{tabular}

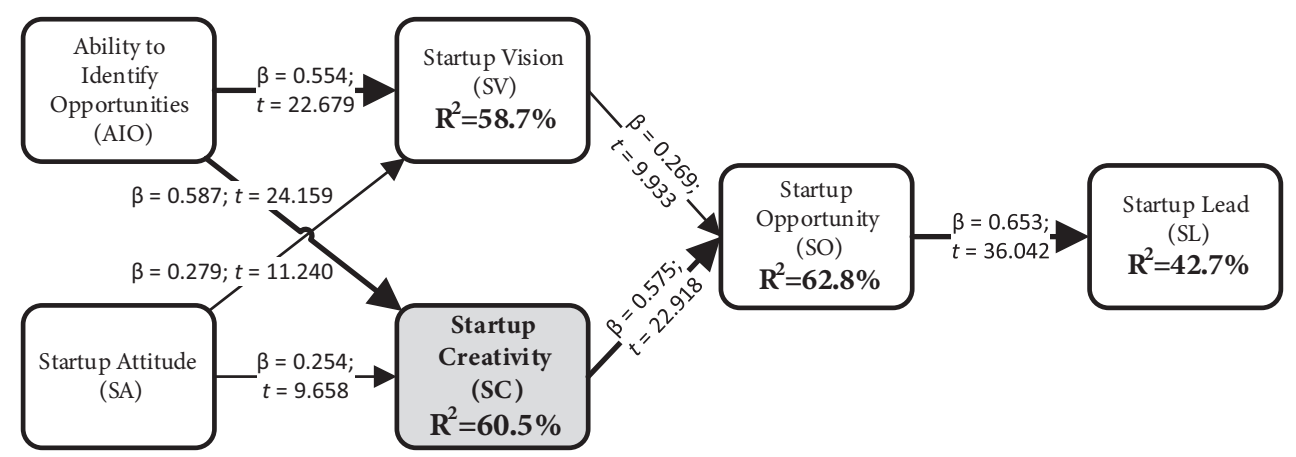

Figure 2. Final model (source: created by authors) 


\section{Discussion}

As can be seen in Figure 2, the confidence level test for the model is higher than $99.9 \%$. This means that this model can explain the determinants of SL, which is the name given to entrepreneurship initiative in this study. The explanatory capacity of the endogenous constructs is also high, especially SO and SC, which shows that both creativity and opportunity are very important determinants for the model.

Figure 2 also shows the relationships with the greatest loads, indicating influence, are represented by thicker arrows. The most influential relationship is AIO with SC, which means that the attitude and AIO are the most important factors which condition creativity. Therefore, the creativity of a startup will be conditioned by the amount of these two competences that the entrepreneur has, especially for the social, cultural and economic assessment of the opportunities, the potential that an idea has for creating value and the ability to identify the most appropriate way to maximize the entrepreneurial idea. These are also important for the capacity to work on several ideas and opportunities together, experiment with innovative approaches and to combine knowledge and resources to achieve results in daily life.

SO is conditioned by both creativity and vision, with creativity being the most influential.

The aim of this research was to identify the main factors that affect creativity in startups and how these factors can influence entrepreneurial initiative strategies. It has been shown that the items for opportunity, (such as, how to identify and take advantage of opportunities, the creation of value in the social, cultural and economic environment, the needs and challenges that must be met and, the ability to gather elements from the environment to create opportunities that create value) are all conditioned by aspects of creativity (such as the ability to work on various ideas and opportunities at the same time, experiment with innovative approaches and combine knowledge and resources to achieve results in the daily life of the entrepreneur).

Both competences measured by these constructs (creativity and vision) have a high value of explained variance, which shows their importance in the final model.

Finally, SO has a very high load on SL. In fact, it has the highest load value in the model, so the competences of being able to identify and take advantage of opportunities to create value in the social, cultural and economic environment, identifying the needs and challenges that must be met and, being able to gather elements of the environment to create opportunities that serve to create value, are all important for a successful entrepreneurial initiative. The entrepreneur must be able to accept challenges easily and be independent when working to reach objectives or planned tasks.

\section{Conclusions}

\section{a. Theoretical implications}

This results from the work carried out in this paper have two main theoretical implications.

On the one hand, all entrepreneurial initiative must have large amount of creativity and initiative to be successful. Past studies have been interested in external factors that directly or indirectly affect creativity, such as digital marketing or data analysis strategies to detect business opportunities. 
A lot of research has been carried out on the internal aspects of an entrepreneurial initiative from a theoretical point of view, that is, the entrepreneur's abilities to make creative decisions or, the type of leadership that is needed to encourage creativity among entrepreneurs.

In this study we have taken into account the internal aspects that affect creativity, especially the ability of the entrepreneur to identify business opportunities, and the entrepreneur's attitude to finding out how these abilities influence the creative and innovative processes of SL.

As it is stated in the $\mathrm{H} 3$, the ability to identify opportunities for startup teams influences the creativity of their strategies as well as the vision of startup projects (H4). The role that ability plays to identify business opportunities is enormous, as a necessary step when taking creative business decisions. The theoretical implications are extensive. On the one hand, creativity does not depend as much on the technology used as on the acquired internal capacities, and therefore, are not innate in the person. That personal ability to successfully explore the market are based on developing certain skills such as become confident with themselves, developing own knowledge about own needs, aspirations as well as strengths and weaknesses to managing emerging companies. Those abilities are acquired through a learning process to develop entrepreneurial initiatives and channeling the common entrepreneurial challenges to achieve the planned tasks. Reaching that behavioral point, the entrepreneurs will be able to influence the course of event, no matter the level of market uncertainty, setbacks and failures. On the other hand, when talking about skills, each of the aspects that relate directly to the theoretical and practical knowledge of the entrepreneur must be analyzed from a theoretical point of view.

The second theoretical implication looks at the role played by the "vision" of the entrepreneurial initiative as it is mentioned in H7. That entrepreneurial vision influences the capture of new opportunities. These new scenarios allow the entrepreneurs to imagine the future, turning ideas into actions by coordinating efforts and actions. This is a second "internal skill", not of "cognitive or attitudinal abilities" but rather "imaginative capacities". Innovative ideas, by themselves, are not enough; they are just one element of the journey towards market domination. Startups have to apply innovation in an intelligent way that actually solves their customers' problems. These are not so much in the volitional dimension, which is where the former exist, but in the imaginative and emotional dimension, so that future possibilities can be "seen" in the present. This is the main difference between how startups and traditional companies approach innovation.

\section{b. Practical implications}

Two practical implications, which are directly related to the improvement of the entrepreneurial initiative among potential entrepreneurs, can be concluded from the results found in this research. The first is that any creative process must take into account the ability to identify opportunities in the social, economic, technological and cultural areas as it is conveyed in (H5), This requires a learning process to be used which gives importance to the acquirement of these skills. 
Practically, this means training for entrepreneurs must be given with an approach that guarantees the acquisition of this "attitude" and a positive predisposition. That teams' attitude influences the vision for startup projects (H2) and the creativity of the startups' strategies (H1). Then, it is crucial not only to enhance the ability to identify business opportunities and put them into practice, but to deploy positive attitudes towards failure, which could be acquire along the entrepreneurs' life and work. As positive attitude toward failure may become a significant asset for the emerging employers. It definitely helps them to deal with and learn from their mistakes and to move forward.

The second practical implication is the importance of the development of creativity not only to impact the audience to which the product or service is directed, but also to use creativity to help and contribute to building a fairer and more equitable society. As it is stated in the H6, creativity influence not only the ability to identify startup opportunities but also the developing new strategies. Environmental and social start-ups are currently on the increase, not only in Spain, but also internationally. The evolution of green entrepreneurs has recently translated into the appearance of many green start-ups in a wide variety of sectors, business strategies, and marketing targets. These entrepreneurs have created products and services to meet green and social dimension linked to the environment to ascertain the problems suffered by the community. It brings a range of new social values to profits, environment, and fair trade (Robina-Ramírez, Human Forthcoming).

Creativity combined with social and environmental benefits have meant that many companies have improved their corporate social responsibility policies, and therefore, have indirectly contributed to improving the company's income.

The research question posed in this study is answered by both the theoretical and practical implications found. The question was "What factors positively affect the creativity processes in startups and how do these influence companies when creating entrepreneurial strategies?". This work gives ideas to individual companies and entrepreneurs on how to train more creative and innovative individuals.

\section{Limitations and recommendations}

Among the main limitations of this study is the absence of in-depth interviews with potential and real entrepreneurs. The collected information would have been more exhaustive, and the conclusions of the work may have been enriched.

The second limitation is the lack of segmentation of the individuals in the sample to differentiate the results. The results could have possibly been different depending on the different views taken by the students, technicians or teachers. This lack of discrimination means that a second study could be undertaken to find the different opinions of the groups in the sample in order to enrich the discussion and debate about which contents must be taught and are needed by the different learners.

The third limitation is the lack of methods to effectively improve the attitudes of potential entrepreneurs.

The results recommend investing time and efforts in improving entrepreneur's abilities to identify opportunities, as well as their attitude to carrying out this identification process. 
However, the phases or steps which should be followed to achieve this are not stated. This new aspect will be part of the following study, which will use the empirical results obtained in this paper.

\section{References}

Aisyah, S., Musa, Ch. I., \& Ramli, A. (2017). Effect of characteristics and entrepreneurial orientation towards entrepreneurship competence and crafts and arts small and medium enterprises business performance in Makassar. International Review of Management and Marketing, 7(2), 166-173.

Aldrich, H. E., \& Martinez, M. A. (2015). Why aren't entrepreneurs more creative? Conditions affecting creativity and innovation in entrepreneurial activity. In Ch. E. Shalley, M. A. Hitt, \& J. Zhou (Eds.), The Oxford handbook of creativity, innovation, and entrepreneurship (pp. 445-456). Series: Oxford Library of Psychology. P. E. Nathan (Ed.-in-Chief). Oxford University Press.

Almeida, P., Dokko, G., \& Rosenkopf, L. (2003). Startup size and the mechanisms of external learning: increasing opportunity and decreasing ability? Research Policy, 32(2), 301-315. https://doi.org/10.1016/S0048-7333(02)00101-4

Audretsch, D. B., \& Belitski, M. (2013). The missing pillar: the creativity theory of knowledge spillover entrepreneurship. Small Business Economics, 41, 819-836. https://doi.org/10.1007/s11187-013-9508-6

Ben Chikha, I., \& Jarboui, A. (2017). Impact of incubators on social entrepreneurship intention: an empirical study related to Tunisia. International Journal of Social Entrepreneurship and Innovation, 4(4), 305-323. https://doi.org/10.1504/IJSEI.2017.089471

Bennett, D., Pérez-Bustamante Yábar, D., \& Saura, J. R. (2017). University incubators may be socially valuable, but how effective are they? A case study on business incubators at universities. In M. PerisOrtiz, J. A. Gómez, J. M. Merigó-Lindahl, \& C. Rueda-Armengot (Eds.), Entrepreneurial universities: exploring the academic and innovative dimensions of entrepreneurship in higher education (pp. 165-178). Series: Innovation, Technology, and Knowledge Management. Springer International Publishing AG. https://doi.org/10.1007/978-3-319-47949-1_11

Chin, W. W. (2010). How to write up and report PLS analyses. In V. E. Vinzi, W. W. Chin, J. Henseler, \& H. Wang (Eds.), Handbook of partial least squares: concepts, methods and applications (pp. 655-690). Series: Springer Handbooks of Computational Statistics. Springer-Verlag. https://doi.org/10.1007/978-3-540-32827-8_29

Chin, W. W., \& Dibbern, J. (2010). An introduction to a permutation based procedure for multigroup PLS analysis: results of tests of differences on simulated data and a cross cultural analysis of the sourcing of information system services between Germany and the USA. In V. E. Vinzi, W. W. Chin, J. Henseler, \& H. Wang (Eds.), Handbook of partial least squares: concepts, methods and applications (pp. 171-193). Series: Springer Handbooks of Computational Statistics. SpringerVerlag. https://doi.org/10.1007/978-3-540-32827-8_8

Chu, F. T., Kolodny, A. J., Maital, Sh., \& Perlmutter, D. (2004, 18-21 October). The Innovation paradox: reconciling creativity and discipline how winning organizations combine inspiration with perspiration. Proceedings of 2004 IEEE International Engineering Management Conference (pp. 949-953). Singapore.

Cohen, P. R., \& Howe, A. E. (1988). How evaluation guides AI research. AI Magazine, 9(4), 35-43.

Cooper, A., \& Folta, T. (2017). Entrepreneurship and high-technology clusters. In D. L. Sexton \& H. Landström (Eds.), The Blackwell handbook of entrepreneurship (pp. 348-367). Wiley-Blackwell. https://doi.org/10.1002/9781405164214.ch17

DiPietro, W. R., \& Anoruo, E. (2006). Creativity, innovation, and export performance. Journal of Policy Modeling, 28(2), 133-139. https://doi.org/10.1016/j.jpolmod.2005.10.001 
Duchesne, C., Kourti, Th., \& MacGregor, J. F. (2002). Multivariate SPC for startups and grade transitions. AIChE Journal, 48(12), 2890-2901. https://doi.org/10.1002/aic.690481216

Endrik, Giri Sucahyo, Y., Ruldeviyani, Y., \& Gandhi, A. (2019, 27-28 October). An empirical study on factors that influence the digital startup sustainability: the mixed methods approach in Indonesia. Proceedings of 10th International Conference on Advanced Computer Science and Information Systems, ICACSIS 2018 (pp. 119-124). Yogyakarta, Indonesia. https://doi.org/10.1109/ICACSIS.2018.8618241

Ensley, M. D., Hmieleski, K. M., \& Pearce, C. L. (2006). The importance of vertical and shared leadership within new venture top management teams: implications for the performance of startups. The Leadership Quarterly, 17(3), 217-231. https://doi.org/10.1016/j.leaqua.2006.02.002

Farinha, L., Ferreira, J. J., Nunes, S., \& Ratten, V. (2017). Conditions supporting entrepreneurship and sustainable growth. International Journal of Social Ecology and Sustainable Development, 8(3), 67-86. https://doi.org/10.4018/IJSESD.2017070105

Fornell, C., \& Larcker, D. F. (1981). Evaluating structural equation models with unobservable variables and measurement error. Journal of Marketing Research, 18(1), 39-50.

https://doi.org/10.1177/002224378101800104

Freeman, J., \& Engel, J. S. (2007). Models of innovation: startups and mature corporations. California Management Review, 50(1), 94-119. https://doi.org/10.2307/41166418

Hair, J. F., Ringle, Ch. M., \& Sarstedt, M. (2011). PLS-SEM: indeed a silver bullet. Journal of Marketing Theory and Practice, 19(2), 139-152. https://doi.org/10.2753/MTP1069-6679190202

Hair, Jr. J. F., Hult, G. T. M., Ringle, Ch. M., \& Sarstedt, M. (2017). A Primer on Partial Least Squares Structural Equation Modeling (PLS-SEM). SAGE Publications, Inc. https://doi.org/10.15358/9783800653614

Helbert, E. (2016). Creativity in crisis: creative climate of failing startups: how does crisis influence the creative climate of failing startups? (Master's Thesis). Technical University Berlin. Berlin, Germany/ University of Twente. Enschede, Netherlands. https://pdfs.semanticscholar.org/1caf/8cf14fb9dd65 021ad0acb51a9f21af23af7d.pdf?_ga=2.249431047.1620516215.1584210206-199233841.1528889777

Henseler, J., Ringle, Ch. M., \& Sarstedt, M. (2015). A new criterion for assessing discriminant validity in variance-based structural equation modeling. Journal of the Academy of Marketing Science, 43, 115-135. https://doi.org/10.1007/s11747-014-0403-8

Henseler, J., Ringle, Ch. M., \& Sarstedt, M. (2016). Testing measurement invariance of composites using partial least squares. International Marketing Review, 33(3), 405-431. https://doi.org/10.1108/IMR-09-2014-0304

Hitt, M., \& Ireland, R. D. (2017). The intersection of entrepreneurship and strategic management research. In D. L. Sexton \& H.Landström (Eds.), The Blackwell handbook of entrepreneurship (pp. 45-63). Wiley-Blackwell. https://doi.org/10.1002/9781405164214.ch3

Hooi, H. Ch., Ahmad, N. H., Amran, A., \& Abidur Rahman, S. (2016). The functional role of entrepreneurial orientation and entrepreneurial bricolage in ensuring sustainable entrepreneurship. Management Research Review, 39(12), 1616-1638. https://doi.org/10.1108/MRR-06-2015-0144

Howley, M. J., \& Malamis, P. (2014). The metrics behind high performing study startups. Applied Clinical Trials, 23(6). http://www.appliedclinicaltrialsonline.com/metrics-behind-high-performingstudy-startups

Kazanjian, R. K., Drazin, R., \& Glynn, M. A. (2002). Implementing strategies for corporate entrepreneurship: a knowledge-based perspective. In M. A. Hitt, R. D. Ireland, S. M. Camp, \& D. L. Sexton (Eds.), Strategic entrepreneurship: creating a new mindset (pp. 173-199). Series: Strategic Management Society. M. A. Hitt (Series Ed.). Blackwell Publishers Ltd. https://doi.org/10.1002/9781405164085.ch9

Kiani Mavi, R., \& Amin Afshar, Z. (2017). The relationships between social capital and organisational entrepreneurship at small and medium enterprises of Zanjan Province. International Journal of Business Innovation and Research, 12(4), 449-464. https://doi.org/10.1504/IJBIR.2017.082827 
King, R. G., \& Levine, R. (1993). Finance, entrepreneurship and growth: theory and evidence. Journal of Monetary Economics, 32(3), 513-542. https://doi.org/10.1016/0304-3932(93)90028-E

Kline, R. B. (2010). Promise and pitfalls of structural equation modeling in gifted research. In B. Thompson \& R. F. Subotnik (Eds.), Methodologies for conducting research on giftedness (pp. 147169). American Psychological Association. https://doi.org/10.1037/12079-007

Kock, N. (2015). Common method bias in PLS-SEM: A full collinearity assessment approach. International Journal of e-Collaboration, 11(4), 1-10. https://doi.org/10.4018/ijec.2015100101

Kock, N., \& Lynn, G. S. (2012). Lateral collinearity and misleading results in variance-based SEM: an illustration and recommendations. Journal of the Association for Information Systems, 13(7), 546-580. https://doi.org/10.17705/1jais.00302

Kuo, P.-Y., \& Gerber, E. (2012, May). Design principles: crowdfunding as a creativity support tool. In CHI EA'12: CHI '12 Extended Abstracts on Human Factors in Computing Systems (pp. 1601-1606). New York, United States. Association for Computing Machinery. https://doi.org/10.1145/2212776.2223679

Lee, C., Hallak, R., \& Sardeshmukh, Sh. R. (2016). Innovation, entrepreneurship, and restaurant performance: a higher-order structural model. Tourism Management, 53, 215-228. https://doi.org/10.1016/j.tourman.2015.09.017

Marlet, G., \& Woerkens, van C. (2004). Skills and creativity in a cross-section of Dutch cities. Utrecht School of Economics, Tjalling C. Koopmans Research Institute. Discussion Paper Series 04-29. https://dspace.library.uu.nl/handle/1874/7392

Mas-Tur, A., Roig-Tierno, N., \& Ribeiro Soriano, D. (2016, 9-12 February). Barriers to women entrepreneurship. PLS vs. QCA: do different methods yield different results? Proceedings of 21st International Academic Conference (138 p.). Miami, United States. https://doi.org/10.20472/IAC.2016.021.024

Mazzarol, T., Volery, Th., Doss, N., \& Thein, V. (1998, 8 June). Creativity drives the dream: an empirical analysis of the factors motivation business start-ups. ICSB World Conference. Singapore. https://www. researchgate.net/profile/Tim_Mazzarol/publication/36390854_Creativity_drives_the_dream_An_empirical_analysis_of_the_factors_motivation_business_start-ups/links/58d5b543a6fdcclbae66eelf/ Creativity-drives-the-dream-An-empirical-analysis-of-the-factors-motivation-business-start-ups.pdf

Meyer, G. D., Neck, H. M., \& Meeks, M. D. (2002). The entrepreneurship-strategic management interface. In M. A. Hitt, R. D. Ireland, S. M. Camp, \& D. L. Sexton (Eds.), Strategic entrepreneurship: creating a new mindset (pp. 17-44). Series: Strategic Management Society. M. A. Hitt (Series Ed.). Blackwell Publishers Ltd. https://doi.org/10.1002/9781405164085.ch2

Montiel Campos, H., Solé Parellada, F., Ruiseñor Quintero, M., \& Aguilar Valenzuela, F. A. (2015). Creative thinking style and the discovery of entrepreneurial opportunities in startups. Revista de Negócios: Studies on Emerging Countries, 20(1), 3-12. https://doi.org/10.7867/1980-4431.2015v20n1p3-12

Nambisan, S. (2017). Digital entrepreneurship: toward a digital technology perspective of entrepreneurship. Entrepreneurship Theory and Practice, 41(6), 1029-1055. https://doi.org/10.1111/etap.12254

Podsakoff, Ph. M., MacKenzie, S. B., Lee, J.-Y., \& Podsakoff, N. P. (2003). Common method biases in behavioral research: a critical review of the literature and recommended remedies. Journal of Applied Psychology, 88(5), 879-903. https://doi.org/10.1037/0021-9010.88.5.879

Reynolds, P. D. (2001). National panel study of U.S. business startups: background and methodology. Databases for the Study of Entrepreneurship, 4, 153-227. https://doi.org/10.1016/S1074-7540(00)04006-X

Ringle, C. M., Silva, da D., \& Bido, D. (2014). Structural equation modeling with the SmartPLS. REMark - Revista Brasileira de Marketing, 13(2), 56-73. https://doi.org/10.5585/remark.v13i2.2717

Robina-Ramírez, R., Fernández-Portillo, A., \& Díaz-Casero, J. C. (2019). Green start-ups' attitudes towards nature when complying with the corporate law. Complexity. http://downloads.hindawi.com/ journals/complexity/2019/4164853.pdf 
Robina Ramírez, R., \& Human, G. (Forthcoming). How macro level foundations influence emerging micro entrepreneurial activities: the case of South Africa. Entrepreneurship and Sustainability Issues.

Roldán, J. L., \& Sánchez-Franco, M. J. (2012). Variance-based structural equation modelling: guidelines for using partial least squares in information systems research. In M. Mora, O. Gelman, A. Steenkamp, \& M. S. Raisinghani (Eds.), Research methodologies, innovations and philosophies in software systems engineering and information systems (pp. 193-221). Series: Premier Reference Source. Business Science Reference. https://doi.org/10.4018/978-1-4666-0179-6.ch010

Rutten, J. (2014). Do incubators stimulate innovation performance in startups through openness? (Master's Thesis). Eindhoven University of Technology. Eindhoven, Netherlands. https://pdfs.semanticscholar. org/8de4/bc97a11f1cd9ece8be53fc36fd2e525f8811.pdf?_ga=2.47588391.1620516215.1584210206199233841.1528889777

Saura, J. R., \& Bennett, D. R. (2019). A three-stage methodological process of data text mining: A UGC business intelligence analysis. Symmetry, 11(519). https://www.mdpi.com/2073-8994/11/4/519

Saura, J. R., Palos-Sanchez, P. R., \& Correia, M. B. (2019a). Digital marketing strategies based on the e-business model: literature review and future directions. In A. Guerra Guerra (Ed.), Organizational Transformation and Managing Innovation in the Fourth Industrial Revolution (pp. 86-103). Series: Premier Reference Source. Business Science Reference. https://doi.org/10.4018/978-1-5225-7074-5.ch005

Saura, J. R., Palos-Sanchez, P., \& Grilo, A. (2019b). Detecting indicators for startup business success: sentiment analysis using text data mining. Sustainability, 11(917). https://www.mdpi.com/2071-1050/11/3/917

Sulistyo, H., \& Siyamtinah. (2016). Innovation Capability of SMEs through entrepreneurship, marketing capability, relational capital and empowerment. Asia Pacific Management Review, 21(4), 196-203. https://doi.org/10.1016/j.apmrv.2016.02.002

Ven, Van de A. H., Hudson, R., \& Schroeder, D. M. (1984). Designing new business startups: entrepreneurial, organizational, and ecological considerations. Journal of Management, 10(1), 87-108. https://doi.org/10.1177/014920638401000108

Venkataraman, S. (2019). The distinctive domain of entrepreneurship research. In J. A. Katz \& A. C. Corbett (Eds.), Seminal Ideas for the Next Twenty-Five Years of Advances, Vol. 21: Advances in Entrepreneurship, Firm Emergence and Growth (pp. 5-20). J. A. Katz \& A. C. Corbett (Series Eds.). Emerald Publishing Limited. https://doi.org/10.1108/S1074-754020190000021009

Welter, F., Baker, T., Audretsch, D. B., \& Gartner, W. B. (2017). Everyday entrepreneurship - a call for entrepreneurship research to embrace entrepreneurial diversity. Entrepreneurship Theory and Practice, 41(3), 311-321. https://doi.org/10.1111/etap.12258

Yolanda, Y., \& Syuraini, S. (2019). Description of learning implementation in entrepreneurship courses package C program at PKBM Farilla Ilmi Padang. Indonesian Journal of Contemporary Education, $1(1), 41-43$.

Yunis, M., Tarhini, A., \& Kassar, A. (2018). The role of ict and innovation in enhancing organizational performance: the catalysing effect of corporate entrepreneurship. Journal of Business Research, 88, 344-356. https://doi.org/10.1016/j.jbusres.2017.12.030

Zahra, Sh. A., \& George, G. (2002). International entrepreneurship: the current status of the field and future research agenda. In M. A. Hitt, R. D. Ireland, S. M. Camp, \& D. L. Sexton (Eds.), Strategic entrepreneurship: creating a new mindset (pp. 253-288). Series: Strategic Management Society. M. A. Hitt (Series Ed.). Blackwell Publishers Ltd. https://doi.org/10.1002/9781405164085.ch12

Zapatero, M. R., Pérez Naranjo, L., Rodríguez Jiménez, M., \& Ramírez Faz, I. (2018). Using PLS-SEM to model family business behavior when addressing the protocol. European Journal of Family Business, 8, 151-160. https://doi.org/10.24310/ejfbejfb.v8i2.5567 


\title{
KAIP İSITIKINIMAI, POŽIŪRIS IR GEBĖJIMAS PASINAUDOTI GALIMYBĖMIS DARO ITTAKĄ STARTUOLIŲ VERSLO KŪRYBIŠKUMUI
}

\author{
Pedro PALOS-SANCHEZ, José Ramón SAURA, Antonio GRILO, \\ Rafael ROBINA RAMIREZ
}

Santrauka

Šiame straipsnyje nagrinejjami pagrindiniai veiksniai, darantys ịtaką startuolių kūrybiškumui ir prisidedantys prie antrepreneriškų iniciatyvinių strategijų. Penkiasdešimt žmonių iš Ekstramadūros regiono (Ispanija) 2018-2019 m. dalyvavo internetinèje apklausoje. Kintamųjų sąveikos modeliui sukurti buvo naudojamasi SmartPLS kompiuterine programa. Gauti rezultatai yra svarbūs teoriškai ir praktiškai, nes naujausioje literatūroje jie papildè naujus atradimus apie tai, kokị vaidmenị ¡̇vairūs veiksniai atliko startuolių kūrybiškumo procesuose. Modeliui būdinga stipri prognostinè galia $\left(R^{2}=42,7 \%\right)$. Šiame straipsnyje aprašomi vidiniai veiksniai, tokie kaip intelektiniai ir su požiūriu susiję gebejjimai, kuriuos pasitelkiant, verslo galimybės nustatomos kaip parengiamasis žingsnis prieš priimant kūrybinius verslo sprendimus, taip pat sudarant palankias sąlygas ateityje derinant galimas pastangas ir veiksmus.

Reikšminiai žodžiai: kūrybiškumas, antreprenerystė, mažiausiųjų dalinių kvadratų struktūrinių lygčių modeliavimas, startuolių verslas. 